\title{
BUFFALO TO MRIDANGAM
}

\author{
* Keshar A. Bulbule
}

\section{Introduction}

Among God's mind boggling creations, the human being is unique in many ways and perhaps His most innovative work. Among the Homosapiens the creative person is not only rare but also amongst the finest species. Relentlessly searching for that special quality which cannot be quantified, but is very much there for the connoisseur to perceive and enjoy.

According to legend, 'The Origin of Music' is traced in 'OM', the 'Naad Brahma' or the sound made by Lord Brahma, from which all other sounds including music emanated. The first step towards making musical instruments like Tabla, Khanjeera, Mridangam efc., begins with slaughtering of the cattle.

According to Nobel laureate Sir. C. V. Raman, 'Mridangam', a "double headed leather drum is the king of percussion instruments".

The traditional technique of leather tanning discussed in this volume, explains the devoted and selfless work of the men behind musical instruments, the eco-friendly and pollution free technique practiced for centuries, various plant products and their action in converting the soluble protein into insoluble leather. Going through the contents, I am sure that one will have the experience as though he/she is seeing the actual tanning process.

* Prof. in Chemistry, K.L.E. Society's S. Nijalingappo College, Bangalore. 
"The process of converting raw animal hide or skin into leather is called Tanning."

Knowledge of tanning seems to have been acquired in prehistoric age. Throughout the Middle Age tanning flourished in Europe, North Africa and the near East.

Eskimos (ice-age men) used animal skins to protect their body against inclement weather and their feet against thorns and rocks. Preserved specimen of leather dating back to 5000 B.C. have been found.

By the end of 18 th century, the principles of vegetative tanning were well understood. The specialized instruments and the crude machines were in use. When scientific basis for the action of tannic acid was not formulated, the values of materials such as oak bark, valonia and menlok were established.

Tanning with chromium salts, introduced at the end of 19th century, was probably the first change in the chemistry of leather production. Scientific principles have transformed tanning from an art to an industrial process that can be carried out wherever suitable raw materials are available.

The industry provides employment to a large number of people because a tannery can use either a great deal of labour and low capital investment, or a great deal of capital and a low labour supply. Depending upon the process used, this industry can be established in both developing and advanced countries.

Leather's unique properties, rising population, new use of leather, rapid changes in world fashion and more intensive use of resources in developing countries have contributed to an ever-increasing demand for leather.

Leather, as an international commodity, the production and its use worldwide is as follows (as on year 2000 ):

\begin{tabular}{|lr|lc|}
\hline \multicolumn{2}{|l|}{ Million square feet } & \multicolumn{2}{l|}{$\%$ By End Use } \\
\hline Footwear & 11,700 & Footwear & 65 \\
\hline Garments & 3,300 & Garments & 18 \\
\hline Automotive & 400 & Automotive & 2 \\
\hline Furniture & 900 & Furniture & 5 \\
\hline Other leather products & 1,700 & Other leather products & 10 \\
\hline Total & 18,000 & Total & 100.0 \\
\hline
\end{tabular}


The leather trade is concentrated in advanced countries that trade among themselves. The scarcity and high cost of labour, the reluctance of labour to perform operations like dehairing and defleshing which is considered to be the dirtiest of all the professions, the realization that every developing nation is conscious to develop its own industry however have forced the advanced countries to buy more and more finished leather, than buying raw hides and skins from the developing nations.

Traditional technique of leather tanning is discussed with unusual visuals with an intention of exposing the young generation as to how this technique has sustained challenges of new technologies in the field, the men behind the musical instruments, and to learn everything from slaughter house to finished leather.

The most commonly practised types of tanning are:

i) Vegetative tannage,

ii) Synthetic tannage,

iii) Combination tannage (chrome-vegetable combination)

iv) Mineral tannage

Among the above processes, the Vegetative tanning is though ancient, is still practised in some places.

To understand the principles of vegetative tanning, one should know what is hide, composition of 'hide', classification of hides, steps involved in tanning such as curing, liming, dehairing, defleshing, deliming, use of natural products rich in tannins, chemistry involved in tanning, finished leather and commercial applications of leather.

\section{What is a hide?}

Skin stripped off from dead or live goats, pigs, horses, camels, crocodiles, snakes, cattle, etc., are generally called hide. Any hide or skin can be tanned into leather, skins of animals like elephant, zebra, leapord, lion and tiger bring high prices.

Cow's skin is called 'kips', that of buffalo's is called 'buff' and skin of dead cattle is called 'hide'.

Animal skins vary in size, shape, texture, thickness and quality. Quality of hide depends upon how and why animal was nourished, whether it died of old age or 
was slaughtered, age, sex, environment etc. Damage of many kinds, reduces the value of hides and skins. The most common defects encountered are those produced on the live animal by parasites, malnutrition, oldage, brand marks and barbed wire scratches on the dead animal, by poor stripping off the skin, handling and storage.

Generally, buffalo or cow's fresh hide brought from slaughter house is composed of $60-70 \%$ water, $30-35 \%$ proteins, $2 \%$ lipids, $0.5 \%$ carbohydrates and $1 \%$ mineral salts, pigments etc.

Solid matter mostly contains $90.95 \%$ proteins, both fibrous and non-fibrous. Fibrous protein mainly contains over $85 \%$ collagen and the rest is corneum, elastin etc.

Mamalian hides are classified into three layers. distinct in structure and origin. They are:

i) Thin outer layer of epithelial cells called epidermis

ii) Thick layer called corneum or dermis and

iii) Subcutaneous adipose or flesh layer.

One layer of corneum contains the grain membranes hyaline layer together with arrangement of hair and pores, which gives a distinct grain surface pattern for each species of animals.

The other corneum layer is composed of large collagen fibre bundles inter woven at an angle in a three-dimensional network. The fibre structure varies from one species to another and in different parts of the skin, belly loose, butt tight, elastin fibres make leather that stretches. Fatty skins yield spongy leather.

"In tanning, epidermis and flesh layers of hide are removed and only corneum is tanned into leather." Hair and wool are made up of keratinuous fibres. The nonfibrous proteins are water-soluble albumins, water insoluble globulins and glycoproteins.

All soluble proteins are removed before tanning. The fibrous protein chains are held together in position by chemical bonds giving a cohesive' structure that may be broken down by tanning to produce leather. In a way "Science of leather manufacture is the science of skin proteins and their interactions with acids, alkalis, salts and organic and inorganic reagents." 
The process of tanning is completed in two stages:

1. Preparation of hides for tanning

II. Tanning of pretreated hide to produce leather

\section{Preparation of Hides for Tanning:}

The raw skin goes through a series of chemical treatments before it turns into flattened leather. This includes soaking, liming, dehairing. and deliming. All these put together are explained as follows:

a). Curing of hides

b) Dehairing and removal of flesh

c) Deliming

\section{Curing Process}

The process of treating the skin which is obtained from slaughterhouse and preventing it from decay is called curing.

Raw hides should be cured to prevent decay that begins within hours of slaughter. The purpose of curing is to remove undesirable constituents and to condition the skin for tonning. This pretreatment is to treat the hide with common salt and a saturated solution of lime.

\section{Liming of cured Hide}

Hides pretreated with salt and saturated solution of lime, are further kept immersed in a pit filled with lime solution for 8-10 days. The $\mathrm{pH}$ of the solution should be 10 . 12. Longer the period of soaking, better will be the quality of leather produced.

When hides and skins are put into acidic or alkaline solution, the hides absorb a part of the acid or alkali. Out of this absorbed acid or alkali, only a small part reacts with collagen and makes the latter either positively or negatively charged. This along with swelling helps the dehairing process and removal of flesh. Swelling is a distinguished and important property of collagen. Hide saturated with lime is taken out from the pit subjected for dehairing, swollen hide makes dehairing easier. Dehaired hide is reversed and flesh is removed either mechanically or manually. The dehaired defleshed hide is known as pelt. A pelt is taken for the next operation called deliming. 


\section{Deliming}

The process of removal of excess of lime associated with the pelt is called deliming. Before tanning, pelt should be delimed to prevent it from becoming dark in colour and brittle.

If limed pelts are put straight to vegetable tan liquor, without going through deliming process, the lime present on the grain and flesh sides will quickly darken the colour of the vegetable tannins. The colour of the leather will also be extremely dark due to the oxidation of tannins. Moreover, Calcium tannate is insoluble in water and therefore, large amount of tannin will be lost due to precipitation of Calcium tannate. The deposition of insoluble Calcium tannate in the interfibrillary spaces of grain layer develops cracks and leather becomes rough. To prevent this, pelt should be delimed by repeated washing with water or dilute solution of Formic acid.

When limed pelt is delimed, its swelling subsides making the material to absorb tannin from vegetable liquors of higher strengths in drums or pits. Delimed pelt is now ready for tanning.

\section{Tanning of Delimed Pelt}

\section{Tanning}

The process of conversion of hides and skins into insoluble nonputrescible leather without the destruction of original structure is called tanning.

Though the technology has developed very fast, the traditional vegetative technology of tanning has still sustained and survived advancement at all levels of this process. This write-up mainly deals with the Vegetative tanning based on hand-on experience in the field. The experience gained by a family associated with this traditional technique of tanning of leather (Negetative) is shared with the author and is effectively communicated through a number of visuals that explain the very process of tanning of leather from the slaughterhouse to the finished leather, which may not require the reading of detailed text.

Vegetative tanning involves, selection and preparation of materials rich in tannin, leaching of tannic acid, tanning of delimed pelts, rehydration etc., to finally get leather. 


\section{Preparation of materials rich in tannins}

Vegetable tannins are natural organic astringent materials obtained from the plant kingdom. In every country there are a large variety of tannin bearing plants but, their practical application for the production of leather however is depended mainly on two important factors.

i) they must occur in sufficiently large quantities

ii) they must contain enough tannin to its extraction profitable. Beside this the colour, the $\mathrm{pH}$ value, the non-tannin content, the nature of the non-tannins etc., are to be considered so that they produce suitable leathers to meet the market demand.

Generally, vegetative tanning mainly makes use of plant products rich in tannin such as:

i) the bark of Babool tree (Acacia Arabica)

ii) the unripe fruits called Myrobalans (Terminalia Chebula)

Vegetable tanstuffs contain tannins which are amorphous, astringent, complex mixtures of polyphenols and non-tanning materials, including carbohydrates, salts and acids which also contribute to the quality of leather.

Babool trees grow in India, Egypt and Sudan. The bark of the tree was one of the principal tanning materials in the northern India for tanning hides, calf skins for many years. Tanned hides and skins were mainly exported to Great Britain in a rough tanned state.

In India, Babool trees grow scattered naturally and they are not cultivated for commercial purpose. The tannin obtained from the Babool bark of Punjab and U.P. is considered the best. In local Kannada language the tree is called "Jaalimara". The Babool tanning is a mixed type of tanning in which the condensed tanning predominates. The tan and the non-tan ratio varies from $1: 7$ to $1: 9$ and the acid and salt ratio is very near to 1:0. The tannin present in the bark of Babool tree contains several very complex aromatic compounds which may contain saccharides combined with various phenols.

\section{Myrobalans (Terminalia Chebula)}

Myrobalan (in local language "Alalekai") is the unripe fruit of an Indian tree and contains about 35 to $40 \%$ of tannin which gives light pink colour to leather. 
Myrobalan tannin is purely a hydrolysable type of tannin and alone cannotproduce good leather. It is always used in admixture with condensed tannins. The $\mathrm{pH}$ of the Myrobalan tannin gradually goes down due to fermentation of sugary matter present in the content. In Myrobalan tannin is approximately $14 \%$ and of which $5.5 \%$ is sugary matter. The bloom produced by Myrobalan tan liquor is mainly Elagic acid and Chebulic acid.<smiles>O=C(O)c1cc(O)c(O)c(OC(=O)c2cc(O)c(O)c(O)c2)c1</smiles>

Digallic Acid<smiles>O=C(O)c1cc(O)c(O)c(O)c1</smiles>

GallicAcid<smiles>O=C(O)CC(C(=O)O)C1c2c(cc(O)c(O)c2O)C(=O)OC1C(=O)O</smiles>

Chebulic Acid

Tan/non tan ratio varies from 1.5 to 2.5 whereas, salt/acid ratio is as low as 0:03. The outstanding properties of tannins have been summarized as, they are colloidal solutions, possess astringent (binding) properties, precipitate gelatin from solution and form insoluble compounds with certain animal tissues (soluble proteins into insoluble leather). This property is taken advantage in tanning of leather.

Tannin; Galotanic acid, incorrectly Diagallic acid is para diagalloyl ester like compound of Glucose with Mol. Formula $\mathrm{C}_{76} \mathrm{H}_{52} \mathrm{O}_{46}$ \& Mol.wt. 1701.18 as $\mathrm{C}-53.65 \%, \mathrm{H}-3.08 \%$ and $\mathrm{O}-43.26 \%$

In extract manufacture from tannin materials, there are mainly four operations:
a) Grinding or breaking
b) Leaching
c) Tanning
d) Drying 


\section{Grinding or breaking}

In the bark of Babool tree, the tannins are contained in fine capillary tubes running lengthwise in the direction of the plant fibres and are endorsed in an insoluble substance.

In fruits like Myrobalan, the tannins remain in sack. So, the tanning materials must be mechanically broken up in order to make the extraction of soluble tannins possible. The tanning materials are dried to the maximum possible extent and then broken. This drying ruptures to a great extent the sacks in which tannin remains.

The dry and brittle bark Babool, Pine etc., are broken up mechanically or manually, lengthwise. The size of the ground tanning material is very important. If the broken pieces are too big then the extraction of tannin will not be efficient. Dusty materials from lump when come in contact with water prevents extraction. The broken tanning materials should not therefore be too big and should be free from the dust. Drying of tan stuffs under hot sun is generally avoided otherwise, the tannin quality, appreciably goes down.

The crushed pieces of bark of Babool tree and Myrobalan are now put into water placed in a pit. Pit may be made by stone or concrete or wood. The tannins are leached out and the water extract is now rich in tanning agents.

Delimed 'Pelt' is immersed in a pit and kept soaked for atleast 24 to 48 hours. Almost off white pelt now turns to light pink.

After the lapse of 24 to 48 hours, slightly dark coloured pelt is thoroughly washed by dipping it in wash bath consisting of plain water. Washed delimed pelt is taken out, cut into two pieces and then stiched to get the shape of a bag. Bag is again partially packed with crushed mixture of bark of Babool tree and Myrobalan, (it may be fresh or taken out of one of the pits). Two such bags are tied together and made to hang on either side fo the wooden log. Each bag is further filled with the extract rich in tannin. Each bag will be big to hold about 60-70 liters of extract. For rehydration bags are left hanging atleast for another 48 hrs. During this period scudding is done.

Scudding helps the removal of stray hair, fats and traces of lime. Scudding is generally done using a plastic tool or a blunt knife.

After the lapse of $48 \mathrm{hrs}$, bags filled with concentrated tannin, are cut at the bottom. The extract is removed and collected in the pits. This extract can be reused for 4-5 times. Each bag is then cut from the top into two halves. The unused solid, rich in 
tannin is taken out. The wet leather now obtained is tried in shade or sunlight and rolled up. Rolling makes the leather stronger. This finished leather is sent to the market for sale.

Major types of leather and their commercial applications are as follows:

\begin{tabular}{|l|l|}
\hline Group & Applications \\
\hline Cattle & $\begin{array}{l}\text { Boot and shoe sole, heels, inner soles, fancy } \\
\text { goods, hand bags, belts, gloves, hydrolic } \\
\text { packings, washers, lithographic purposes, foot } \\
\text { balls. }\end{array}$ \\
\hline Calf skin & $\begin{array}{l}\text { Bookbindings, sweat bands, military helmets, } \\
\text { glass masks, grips for golf stick. }\end{array}$ \\
\hline Sheep and Lamb & $\begin{array}{l}\text { Slippers, gloves, coats, hats, chamois, } \\
\text { parchments, piano action, rollers on textile } \\
\text { machinery, screens for offset printing machines. }\end{array}$ \\
\hline $\begin{array}{l}\text { Horse, Colt, Ass } \\
\text { Mule, Zeebra hides }\end{array}$ & $\begin{array}{l}\text { Gloves and garments, sporting goods, luggage, } \\
\text { belts. }\end{array}$ \\
\hline $\begin{array}{l}\text { Buffalo Group } \\
\text { (Domestic group) }\end{array}$ & $\begin{array}{l}\text { Shoe soles and uppers, buffing wheels, luggage } \\
\text { and handbags, musical instruments like tabla, } \\
\text { mridangam etc. }\end{array}$ \\
\hline
\end{tabular}

\section{References}

1) Encyclopoedia Britannica 1978 (Micropaedia) VoL $10 . P g$ 759- 764

2) Mc.Grow Hill Encyclopaedia of Science and Technology. 1977

3) 'A- Z of tanning of leather' A publication by Centre for Leather Research Institute, Chennai.

4) Text Book Of Notural Products by PI Soni

5) 'Profiles of creafivity' by Madhu Upadhyay

6) 'Outlook' Monthly Magazine, Page No. 62 Sept. 2003 